\section{BETTER AGREEMENT OVER THE HUMAN STORY}

Dates estimated from DNA evidence conflicted with those from fossil sites that document key events in prehistory, but dates gained using a slower DNA clock are resolving some conflicts.

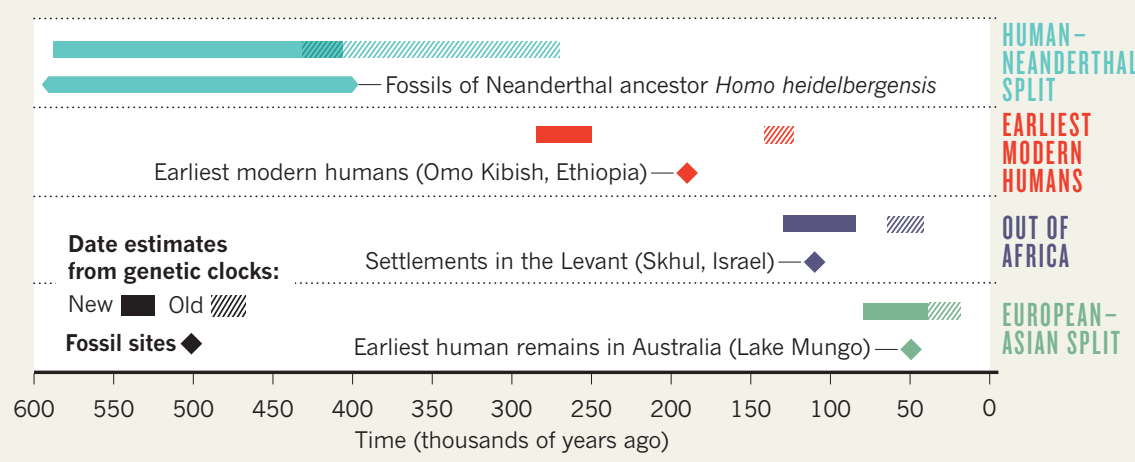

- clock could also force scientists to re-think the timing of later turning points in prehistory, including the migration of modern humans out of Africa. Genetic studies of humans around the world have suggested that the ancestors of Europeans and Asians left Africa about 60,000 years ago. That date caused many to conclude that 100,000-year-old human fossils discovered in Israel represented a deadend migration rather than the beginning of a global exodus, says Scally. Scally's calculations put "out of Africa" closer to 120,000 years ago, suggesting that the Israeli sites represent a launching pad for the spread of humans into Asia and Europe.

The latest genetic dates also fit with several sites in the Middle East that contain tools apparently made by modern humans but dating to around 100,000 years ago. At that time, sea levels between Africa and the Arabian Peninsula were lower than they are now, and a wetter climate would have made the peninsula lush and habitable, perhaps beckoning modern humans out of Africa. Rose, who works one such site, in Oman, says that he "has been over the moon" since reading Scally and Durbin's paper.

The revised molecular clock may also help to settle a debate over whether humans ventured further into Asia more than 60,000 years ago, says Michael Petraglia, an archaeologist at the University of Oxford, UK, who favours an early date.

Although a slowed molecular clock may harmonize the story of human evolution, it does strange things when applied further back in time, says David Reich, an evolutionary geneticist at Harvard Medical School in Boston, Massachusetts. "You can't have it both ways."

For instance, the slowest proposed mutation rate puts the common ancestor of humans and orang-utans at 40 million years ago, he says: more than 20 million years before dates derived from abundant fossil evidence. This very slow clock has the common ancestor of monkeys and humans co-existing with the last dinosaurs. "It gets very complicated," deadpans Reich.

Some researchers, including Scally, have proposed that the mutation rate may have slowed over the past 15 million years, thereby accounting for such discrepancies. Fossil evidence suggests that ancestral apes were smaller than living ones, and small animals tend to reproduce more quickly, speeding the mutation rate.

Little concrete evidence supports this idea, says Reich. He agrees that the molecular clock must be slower than was thought, but says that the question is how slow. "My strong view right now is that the true value of the human mutation rate is an open question." -

1. Scally, A. \& Durbin, R. Nature Rev. Genet. 13, 745-753 (2012).

2. Langergraber, K. E. et al. Proc. Natl Acad. Sci. USA http://dx.doi.org/10.1073/pnas.1211740109 (2012).

3. Hawks, J. Proc. Natl Acad. Sci. USA http://dx.doi. org/10.1073/pnas.1212718109 (2012).

4. Sun, J. X. et al. Nature Genet. http://dx.doi. org/10.1038/ng.2398 (2012).

5. Kong, A. et al. Nature 488, 471-475 (2012).

\title{
Lab-animal flights squeezed
}

\section{Two biggest cargo carriers affirm that they will not ship mammals and non-human primates, as activist pressure mounts to stop research-animal airlifts.}

\section{BY MEREDITH WADMAN}

$\mathrm{F}$ or researchers who rely on lab animals shipped from distant sources, and for the companies that breed them, the options are narrowing again. This week, People for the Ethical Treatment of Animals (PETA) will announce that it has obtained written assurances from the world's two largest aircargo carriers, FedEx and UPS, that they will not transport mammals for laboratory use. UPS says that it is also planning to further "restrict" an exemption that allows the transport of amphibians, fish, insects and other non-mammals.

Neither company currently ships large numbers of lab animals. But PETA, an activist group based in Norfolk, Virginia, sought the carriers' written assurances as a way to foreclose alternatives for lab-animal breeders and their customers, who are increasingly being confronted with bans on transport by passenger airlines. "FedEx and UPS were not transporting many or any animals, but we felt it was crucial to go to them and discuss this as we knew that facilities trying to send non-human primates and other species would be going to them soon, as more and more passenger airlines refused to do business with them," says Kathy Guillermo, PETA's senior vice-president for laboratory investigations.

The commitments will have a direct impact on some researchers. "I am deeply concerned," says Darcy Kelley, a neurobiologist at Columbia
University in New York City, who studies neural and muscular systems involved in vocal communication in the frog Xenopus. The supply companies that Kelley uses - Nasco in Fort Atkinson, Wisconsin; Xenopus One in Dexter, Michigan; and Xenopus Express of Brooksville, Florida - all ship the amphibians by air with UPS for next-day delivery. Losing access to the frogs because of shipping hurdles "would set my research back years", says Kelley. "It takes Xenopus females two years to get to sexual maturity. And maintaining an animal colony is a very expensive proposition."

For those who study mammals, the FedEx and UPS policies may have little immediate impact. The two companies are not used to ship non-human primates internationally, says 
Michael Hsu, president of Shared Enterprises in Richlandtown, Pennsylvania, which maintains a macaque-breeding colony in Shanghai and imports research animals to the United States by air. In the United States, many other lab animals are domestically bred and shipped by truck. But although the FedEx and UPS declarations may be largely symbolic, they suggest that research advocates are failing to make the case for the use of lab animals, and they mark another success for groups such as PETA.

Many large passenger carriers will no longer transport non-human primates after being confronted by PETA and other animal activist groups (see Nature 483, 381-382; 2012). United Airlines and Air France are among the few that have not ruled out primate transport. Air Canada is petitioning the Canadian Transportation Agency for permission to stop the practice. Now, PETA is extending its campaign to other species and to cargo carriers. Non-air transport across international borders is also under pressure. In March, the last two ferry companies transporting laboratory rodents into the United Kingdom said that they were stopping the practice.

FedEx, based in Memphis, Tennessee, says that its commitment not to ship animals reflects a policy that is at least five years old. "There was an active decision made that, especially here in the United States, that's just not how we wanted to do business," says Shea Leordeanu, manager of global public relations for the company. FedEx, the leading global cargo shipper, does occasionally transport animals - for example, it delivered horses to the equestrian events at the London Olympics - but only with special dispensation. Under such exemptions in recent years, as many as several dozen international shipments of research mice have travelled by FedEx annually, Leordeanu says. "However, FedEx has not transported any mice at all in many months," she adds, because customers have not requested its services.

UPS, based in Atlanta, Georgia, has limited animal shipments for more than a decade. With rare exceptions, it ships only amphibians, crustaceans, fish, insects, molluscs and certain lizards and turtles. "We currently are in the process of putting procedures in place to restrict those shipments as well," says Norman Black, director of global media services for UPS, but "the fact that we're considering restrictions doesn't mean a flat ban". The company's policy, he says, is "based both on our sustainability principles and on our marketing decisions. We do not consider animal shipments to be a target market for us, either economically or operationally."

Losing the option of shipping frogs by UPS would be "huge" for his company, says Burley Lilley, president of Xenopus Express, which serves around 100 academic customers throughout the United States. "Part of the reason our business is so good and the animals get there alive is because we use UPS."

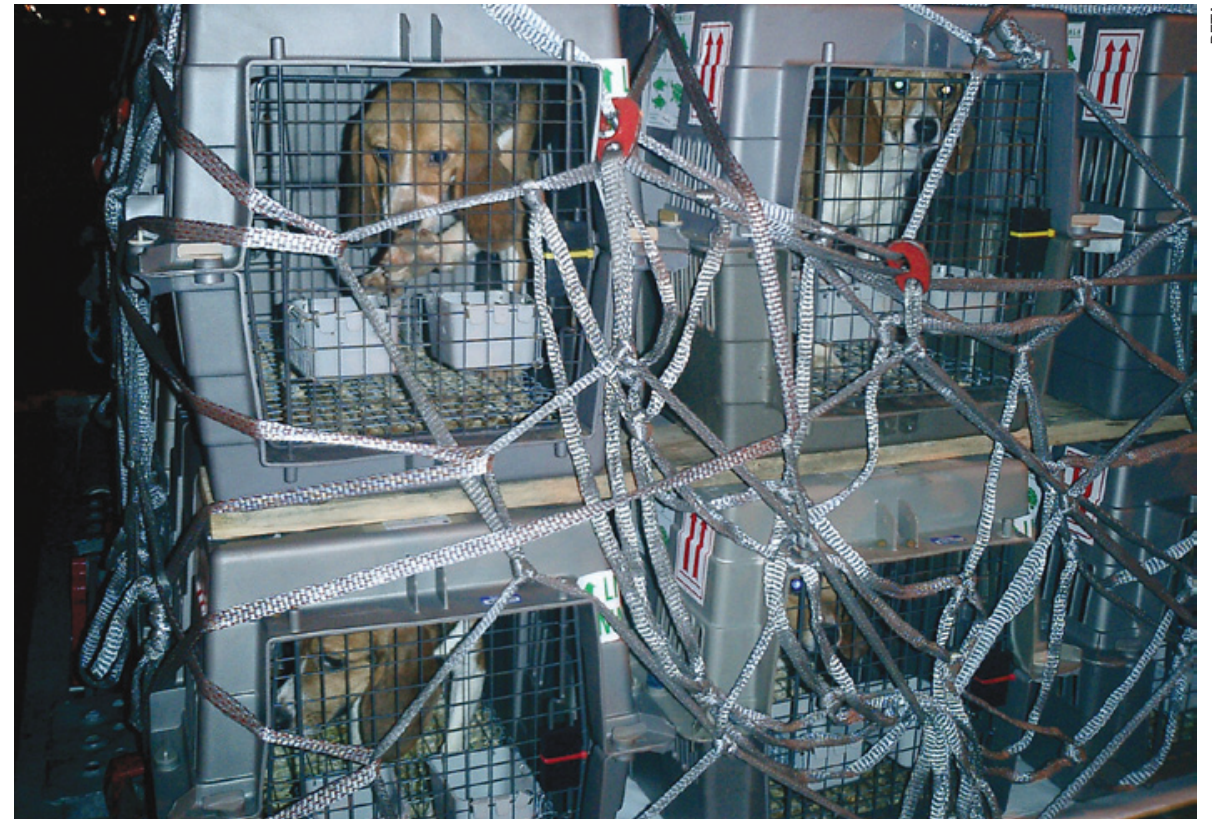

Research beagles being air-freighted by Lufthansa before the carrier changed its policy.

Charles Hewett, executive vice-president and chief operating officer at the Jackson Laboratory in Bar Harbor, Maine, says that less than $10 \%$ of the several million specialized mice that Jackson ships from its US locations each year travel by air; most are shipped domestically by 18 -wheel truck. The laboratory also breeds highly requested strains of mice at facilities overseas, so that they can be delivered quickly by truck.

"We do not use FedEx, we do not use UPS and in fact we believe very strongly that our mice should only be handled by truckers who have been trained to understand the animals' requirements," says

Hewett.

Nonetheless, Hewett says he finds it "troubling that the corporate leaderships of UPS, FedEx and others yield to the pressure of a small

\section{"We do not consider animal shipments to be a target market for us, either economically or operationally."} minority who overlook the importance of what we do for preventing, curing and treating human disease."

For many of its international shipments, Jackson uses a contractor, Charles River Laboratories in Wilmington, Massachusetts, which did not respond to requests for comment. The PETA campaign has had an impact on Charles River in at least one instance. In 2010, less than 24 hours after PETA published a photo of beagles in the cargo hold of a Lufthansa airliner at New York's JFK airport, the German airline said that it would no longer ship dogs and cats for research. The dogs were in transit from research-animal breeder Marshall BioResources in North Rose, New York, to a Charles River Laboratories facility in Scotland. PETA says that it is systematically approaching every major cargo carrier in the world, putting pressure on both international and domestic shipments. In India, for example, the government's National Institute of Nutrition (NIN), in Hyderabad, relies on Air India to ship specialized mouse strains to researchers and companies throughout the country. "From Hyderabad to Delhi by train would take more than 30 hours" and require an attendant, says Madan Chaturvedi, dean of life-sciences research at the University of Delhi. Without Air India transporting the animals, research at his institution "would definitely suffer", he says.

In response to pressure from PETA-India, Air India wrote to the group in July saying "we ... do not accept animals for experimental purposes." On 23 August, Air India issued a circular to all its managers and cargo staff declaring "Air India does not carry 'Live Animals for experimental purposes'”. But Kalpagam Polasa, acting director at the NIN, told Nature last week that weekly flights of her institute's animals on Air India continue, labelled in the 'live animal' category, and costing her institute three times as much as previously. The airline did not respond to requests for comment.

Many scientists may shrug their shoulders at the personal impact of the trend in cargo-carrier policies, says Joseph Haywood, vice-president for science policy at the Federation of American Societies for Experimental Biology in Bethesda, Maryland, and vicepresident for regulatory affairs at Michigan State University in East Lansing, where he is responsible for animal transport for the university. But, he says, "when they need that specific animal model to ask a critical question, they need to have that model. It could be across the street or across the world. We are moving to global science." a SEE EDITORIAL P.366 